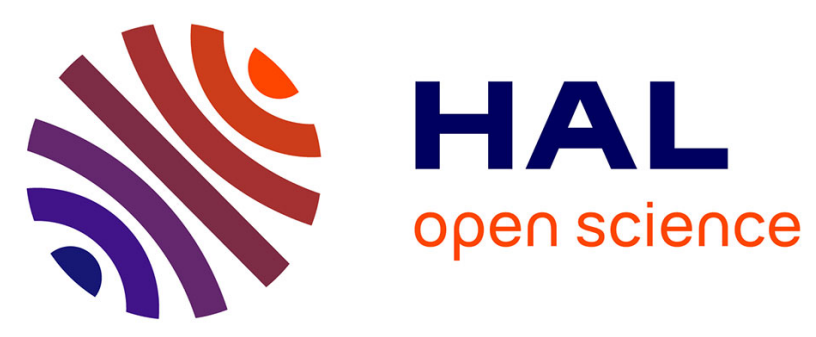

\title{
Preparation and characterization of activated carbon from sewage sludge: carbonization step
}

Sébastien Rio, Catherine Faur-Brasquet, Laurence Le Coq, Didier Lecomte, Pierre Le Cloirec

\section{- To cite this version:}

Sébastien Rio, Catherine Faur-Brasquet, Laurence Le Coq, Didier Lecomte, Pierre Le Cloirec. Preparation and characterization of activated carbon from sewage sludge: carbonization step. Water Science and Technology, 2004, 49 (1), pp.139-146. 10.2166/wst.2004.0041 . hal-00945333

\section{HAL Id: hal-00945333 \\ https://hal.science/hal-00945333}

Submitted on 30 Jun 2021

HAL is a multi-disciplinary open access archive for the deposit and dissemination of scientific research documents, whether they are published or not. The documents may come from teaching and research institutions in France or abroad, or from public or private research centers.
L'archive ouverte pluridisciplinaire HAL, est destinée au dépôt et à la diffusion de documents scientifiques de niveau recherche, publiés ou non, émanant des établissements d'enseignement et de recherche français ou étrangers, des laboratoires publics ou privés. 


\title{
Preparation and characterization of activated carbon from sewage sludge: carbonization step
}

\author{
S. Rio*, C. Faur-Brasquet*, L. Le Coq*, D. Lecomte** and P. Le Cloirec* \\ * Ecole des Mines de Nantes, GEPEA, UMR CNRS 6144, 4 rue Alfred Kastler, BP 20722, 44307 Nantes \\ cedex 3, France (E-mail: Catherine.Faur@emn.fr) \\ ** Ecole des Mines d'Albi-Carmaux, LGPSD, UMR CNRS 2392, route de Teillet, 81013 Albi cedex 9 , \\ France
}

\begin{abstract}
Sewage sludges produced from wastewater treatment plants continue to create environmental problems in terms of volume and method of valorization. Thermal treatment of sewage sludge is considered as an attractive method in reducing sludge volume which at the same time produces reusable by-products. This paper deals with the first step of activated carbon production from sewage sludge, the carbonization step. Experiments are carried out on viscous liquid sludge and limed sludge by varying carbonization temperature and heating rate. The results show that carbonized residue properties are interesting for activated carbon production.
\end{abstract}

Keywords Activation; adsorption; carbonization; sludge; valorization

\section{Introduction}

Wastewater treatment plants produce considerable amounts of liquid waste material called sewage sludge. In France, the production of sewage sludge is about 850,000 tons of dried matter. The traditional ways of sludge valorisation include farmland application, landfill and incineration. However, in France landfill disposal is going to be forbidden from 2002 and farmland applications are more and more questioned by farm-producer industries and even by local elected members and farmers. Furthermore, stringent standards set for preservation of the environment also limit the use of sewage sludge on farmland. Incineration has been a popular disposal technology in recent years but concerns about its rising energy cost, ash disposal and gaseous emissions prevent this method being widely used. So, with some traditional disposal ways coming under pressure and others being phased out, it is necessary to seek cost-effective and innovative solutions to the sewage sludge disposal problem.

Sewage sludge is carbonaceous in nature and rich in organic materials. Therefore, it has the potential to be converted into activated carbon by thermal activation under controlled conditions or with chemical treatment. Activated carbon is widely used in mixture separation, liquid purification and odorous and pollutant gases control emissions. Conventionally, activated carbon is produced from wood, coal or agricultural wastes by physical or chemical activation (Bansal et al., 1988). Today, one promising approach for production of cheap and efficient activated carbon is the use of sewage sludge. Some investigations have been made to show the feasibility of activated carbon preparation from sludge (Calvo et al., 2001; Tay et al., 2001). But, an overall approach to the process is rarely considered and the applications to industrial wastewater or gaseous emissions purification are not usually investigated.

This study focuses on the first step of activated carbon production from raw sewage sludge, the carbonization step. It aims to investigate the effect of carbonization conditions, namely temperature and heating rate, on physico-chemical properties and adsorption capacities of the activated carbons produced. Viscous liquid sludge and limed sludge used as the precursor are collected from the municipal wastewater treatment plant of 
Nantes-Tougas, in France. The use of these two types of sludge enables the effect of lime addition during carbonization process to be studied.

\section{Methods}

\section{Carbonization experiments}

TGA experiments. Thermogravimetric experiments are carried out in a NETZSCH STA 409 PC mode TGA equipment. This apparatus provides the mass variation of a sample during the application of a thermal treatment. Around $1.6 \mathrm{~g}$ of crushed dried sludge are used for each experiment and put down in an alumina crucible. The analyses are carried out up to $1,000^{\circ} \mathrm{C}$ with a heating rate of $20^{\circ} \mathrm{C} / \mathrm{min}$ under nitrogen atmosphere.

Carbonization experiments. Samples of sludge are dried at $105^{\circ} \mathrm{C}$ prior to carbonization experiments, which are carried out in a vertical pyrolysis furnace SLFI 7738 model (volume $=7 \mathrm{~L}$ ), presented in Figure 1. At the beginning of each run, around $150 \mathrm{~g}$ of dried sludge are put on an iron sieve. A nitrogen flow rate of $10 \mathrm{~L} / \mathrm{min}$ is introduced at the bottom of the furnace so that it penetrates the material and evacuates gaseous emissions during carbonization. Carbonization temperature varies from $400^{\circ} \mathrm{C}$ to $800^{\circ} \mathrm{C}$ for limed sludge and from $400^{\circ} \mathrm{C}$ to $1,000^{\circ} \mathrm{C}$ in the case of viscous liquid sludge. Heating rate also varies from $5^{\circ} \mathrm{C} / \mathrm{min}$ to $20^{\circ} \mathrm{C} / \mathrm{min}$ and the carbonization duration is fixed to 1 hour.

Above the carbonization furnace, a condensation system of gaseous emissions permits us to recover the condensable fraction (water and oil) of the gas phase and to clean the noncondensable fraction before evacuation in the atmosphere (Figure 1).

\section{Characterization of the samples}

Sewage sludges. Viscous liquid sludge and limed sludge collected from the municipal wastewater treatment plant of Nantes-Tougas are used in this study. Dried matter content and ash content of the sludge samples are assessed by French standard methods (AFNOR NF U 44-171).

Elemental analysis. The elemental analysis of dried sludges and carbonized sludges are realised with a THERMOQUEST NA2100 elemental analyser given the mass percentage of carbon, oxygen, hydrogen, nitrogen and sulphur.

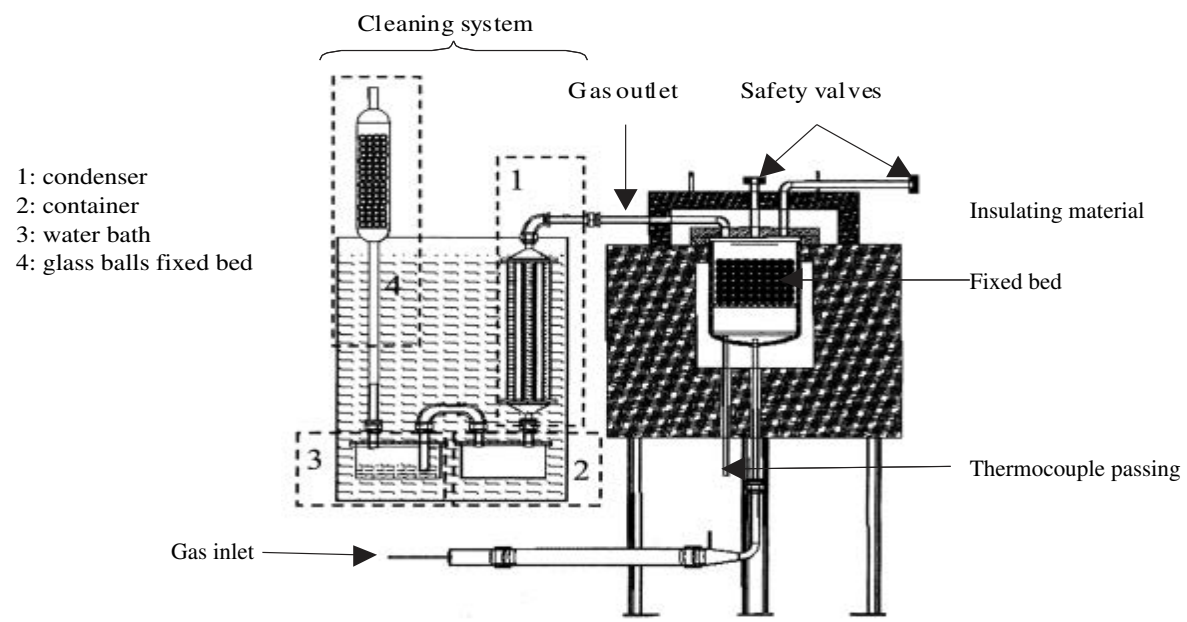

Figure 1 Carbonization experiments apparatus 
Mercury porosimetry. Mesopore (2-50 nm) and macropore (>50 nm) size distributions are estimated with a MICROMERITICS AUTOPORE VI 9500 mercury porosimeter up to $2,000 \mathrm{~atm}$, to estimate the volume constituted by all pores with a diameter from $100,000 \mathrm{~nm}$ down to $8.5 \mathrm{~nm}$.

Nitrogen adsorption isotherm. The nitrogen adsorption/desorption isotherms are measured at $77 \mathrm{~K}$ with a MICROMERITICS ASAP 2010 surface area analyser. Samples are outgassed at $350^{\circ} \mathrm{C}$ in a vacuum for 3 days before analysis. The specific surface area is calculated by BET equation (Brunauer et al., 1938). The mesopore $(2-50 \mathrm{~nm})$ and micropore $(<2 \mathrm{~nm})$ volumes are estimated according to BJH (Barrett et al., 1951) and HK theories (Horvath and Kawazoe, 1983) respectively.

\section{Adsorption tests}

Two typical organic pollutants, namely phenol and benzoic acid, are used to test the adsorption capacities of the carbonized sludges. For each pollutant, several solutions with the same concentration of $100 \mathrm{mg} . \mathrm{L}^{-1}$ are prepared in deionised water. For all the adsorption kinetic experiments, $0.5 \mathrm{~g}$ of carbonized sludge is stirred at $300 \mathrm{rpm}$ in $1 \mathrm{~L}$ of this solution. The temperature is set to $20 \pm 1{ }^{\circ} \mathrm{C}$. During adsorption experiments of organic compounds, the $\mathrm{pH}$ of the mixtures varies from 5.5 to 6.5 .

\section{Results and discussion}

\section{Characteristics of sewage sludges}

The results of physico-chemical analysis of both types of sludge are presented in Table 1 . Limed sludge contains a higher amount of dried matter than viscous liquid sludge, the values are equal to $29.6 \%$ and $19.2 \%$ respectively. During lime addition, dried matter is added and water consumption occurs by hydration of quicklime. Ash content of viscous liquid sludge and limed sludge is equal to $22 \%$ and $29 \%$ respectively. Viscous liquid sludge and limed sludge develop a specific surface area of $2.9 \mathrm{~m}^{2} \cdot \mathrm{g}^{-1}$ and $4.8 \mathrm{~m}^{2} \cdot \mathrm{g}^{-1}$ respectively, and the pore structure of the sludges is mainly macroporous. The difference can be explained by lime macroporosity which increases the specific surface area of the sludge when added.

The results of elemental analysis show that the mass percentages of carbon, hydrogen and nitrogen are higher within viscous liquid sludge even though mass percentages of oxygen and sulphur are equivalent. This decrease of carbon, hydrogen and nitrogen mass percentages is due to dilution effect during lime addition to viscous liquid sludge. Furthermore, $\mathrm{pH}$ raising during liming $(\mathrm{pH}=12)$ involves nitrogen losses by ammonia volatilisation (Barbe et al., 2001). Finally, the sulphur mass percentage is identical within the two types of sludge. But, due to lime addition, the sulphur amount would be lower within the limed sludge. It can be explained by sludge $\mathrm{pH}$ rising limiting the hydrogen sulphide

Table 1 Results of physico-chemical analysis of viscous liquid sludge and limed sludge

\begin{tabular}{lcc}
\hline Property/element & Viscous liquid sludge & Limed sludge \\
\hline Dried matter (wt \%) & 19.2 & 29.6 \\
Ash content (wt \% of dried matter) & 22.0 & 57.0 \\
$\mathrm{~S}_{\mathrm{BET}}\left(\mathrm{m}^{2} \cdot \mathrm{g}^{-1}\right)$ & 2.9 & 4.8 \\
Macroporosity (vol. \%) & 97.0 & 98.0 \\
Carbon & 39.4 & 27.9 \\
Oxygen & 19.8 & 18.7 \\
Hydrogen & 5.6 & 3.5 \\
Nitrogen & 6.4 & 2.9 \\
Sulphur & 0.9 & 0.9 \\
\hline
\end{tabular}


emissions. When $\mathrm{pH}$ is above the value of 10 , sulphur is maintained into sulphides and sulphates (Barbe et al., 2001). This inhibition of hydrogen sulphide emissions does not occur in the case of viscous liquid sludge.

\section{Carbonization experiments}

TGA experiments. The thermogravimetric analysis allows the recording, for each sludge sample, of the mass loss according to temperature and time. Each mass loss is associated to a pyrolysis (or carbonization) reaction within the sample. The results of the analyses carried out on both types of dried sludge are presented in Figure 2. This figure represents the temporal derivative of the mass versus temperature. Each reaction is represented by a minimum or a slope change on the curves.

In the case of viscous liquid sludge, the pyrolysis reactions mainly take place from $200^{\circ} \mathrm{C}$ to about $500^{\circ} \mathrm{C}$, the mass loss being weak between $500^{\circ} \mathrm{C}$ and $1,000^{\circ} \mathrm{C}$. Furthermore, the observation of the temporal derivative of the mass curve reveals that two reactions occur between $250^{\circ} \mathrm{C}$ and $400^{\circ} \mathrm{C}$, because changes of the curve slope appear near $250^{\circ} \mathrm{C}$ and near $320^{\circ} \mathrm{C}$. Another pyrolysis reaction is also identified between $500^{\circ} \mathrm{C}$ and $1,000^{\circ} \mathrm{C}$ because a minimum relating to another reaction is reached at about $800^{\circ} \mathrm{C}$. At $250^{\circ} \mathrm{C}$, separation of water and $\mathrm{CO}_{2}$ would occur and sulphur compounds would be removed. Then, carbonization reactions between $320^{\circ} \mathrm{C}$ and $400^{\circ} \mathrm{C}$ would be attributed to separation of methane and other gaseous hydrocarbons and decomposition of aliphatic compounds, organic acids and organic nitrogen compounds. Finally, when the carbonization temperature is above $600^{\circ} \mathrm{C}$, alteration of bituminous substances in oil would occur followed by cracking of oil into short chain gas hydrocarbons and the formation of aromatic compounds (Bien et al., 2000).

According to the TGA experiment carried out on limed sludge, carbonization reactions occur until a temperature of $1,000^{\circ} \mathrm{C}$. These reactions take place in two very different zones, between $250^{\circ} \mathrm{C}$ and $450^{\circ} \mathrm{C}$ for the first set of reactions, and between $700^{\circ} \mathrm{C}$ and $1,000^{\circ} \mathrm{C}$ for the second set. The curve analysis of the temporal derivative of mass shows that at least three reactions take place in this first zone, near $250^{\circ} \mathrm{C}$, then at $400^{\circ} \mathrm{C}$ and finally, when the temperature reaches $450^{\circ} \mathrm{C}$. The corresponding mass loss of the limed sludge is lower than that observed for the viscous liquid sludge in this range of temperatures. It can be explained by the smaller quantity of organic matter within limed sludge due to lime addition (50\% in mass) during the sludge treatment process. Furthermore, the reaction occurring between $400^{\circ} \mathrm{C}$ and $450^{\circ} \mathrm{C}$ is attributed to a water release within the lime according to the reaction: $\mathrm{Ca}(\mathrm{OH})_{2} \rightarrow \mathrm{CaO}+\mathrm{H}_{2} \mathrm{O}$.

From $700^{\circ} \mathrm{C}$, this curve undergoes a minimum, revealing a further reaction between

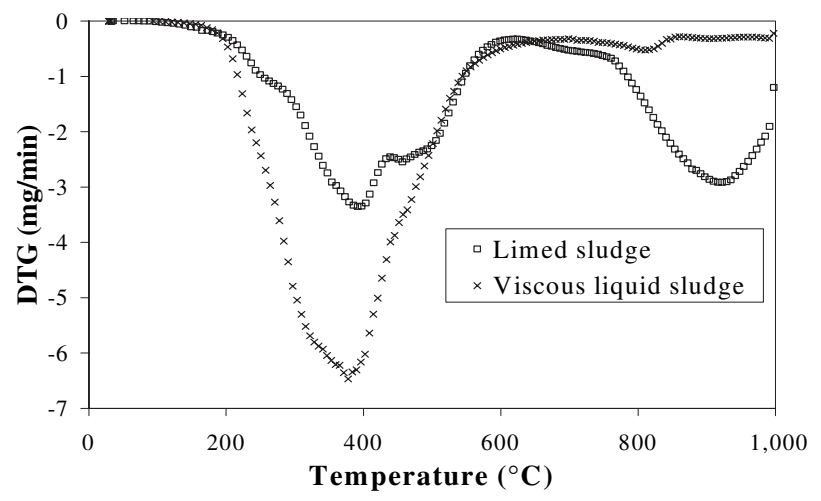

Figure 2 Temporal derivative of the mass versus temperature during TGA experiments 
$700^{\circ} \mathrm{C}$ and $900^{\circ} \mathrm{C}$. This large mass loss from $700^{\circ} \mathrm{C}$ would correspond, notably, to carbonates decomposition within the limed sludge (Zheng and Kozinski, 2000).

Carbonization experiments. During carbonization experiments, carried out on each type of sludge, the influence of temperature and heating rate is studied. The temperature varies from $400^{\circ} \mathrm{C}$ to $1,000^{\circ} \mathrm{C}$ for viscous liquid sludge and from $400^{\circ} \mathrm{C}$ to $800^{\circ} \mathrm{C}$ for limed sludge. The heating rate also varies from $5^{\circ} \mathrm{C} / \mathrm{min}$ to $20^{\circ} \mathrm{C} / \mathrm{min}$ when carbonization temperature is fixed to $600^{\circ} \mathrm{C}$.

Figure 3 represents the effects of temperature and heating rate on carbonization yield (ratio of sludge weight after and before carbonization experiments). Carbonization yield of the limed sludge is higher than viscous liquid sludge one, under the same operating conditions. It is due to the larger quantity of mineral matter in the limed sludge. Then, for both sludges, carbonization yield decreases when carbonization temperature increases. This observation is in agreement with TGA curves which show a mass loss of the samples, even low, until $1,000^{\circ} \mathrm{C}$. Finally, the heating rate seems to have a very weak effect on the carbonization yield.

Elemental analysis has been carried out on carbonized sludge samples to determine mass percentage of carbon, oxygen, hydrogen, nitrogen and sulphur. The results are presented in Table 2. Firstly, carbonized viscous liquid sludge contained more carbon than carbonized limed sludge. It is due to the presence of lime in limed sludge which increases the rate of mineral matter. Moreover, the relatively high quantities of heteroatoms in carbonized sludges, especially oxygen and hydrogen, show that numerous surface functional groups would be present. The oxygen percentage seems to decrease when carbonization temperature increases, i.e. the amount of surface functional groups decreases in the organic fraction and the samples would become more basic (Inguanzo et al., 2002).

Pore size distribution between $8.5 \mathrm{~nm}$ and $100,000 \mathrm{~nm}$ is also determined by mercury porosimetry. The effect of carbonization temperature on pore size distribution of carbonized sludges is presented in Figure 4. As shown in Figure 4, the increase of carboniza-

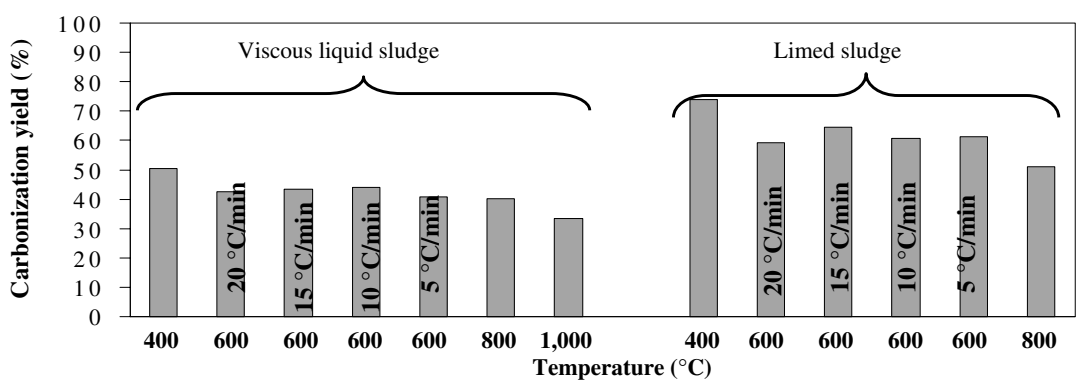

Figure 3 Effect of temperature and heating rate $\left(\right.$ at $\left.600^{\circ} \mathrm{C}\right)$ on carbonization yield

Table 2 Results of elemental analysis of carbonized sludges

\begin{tabular}{lccccc}
\hline Carbonization conditions & Carbon & oxygen & Hydrogen & Nitrogen & Sulphur \\
\hline Viscous liquid sludge, $400^{\circ} \mathrm{C}$ & 32.9 & 15.8 & 2.0 & 4.6 & 0.9 \\
Viscous liquid sludge, $600^{\circ} \mathrm{C}$ & 31.7 & 13.5 & 0.7 & 3.3 & 0.5 \\
Viscous liquid sludge, $800^{\circ} \mathrm{C}$ & 28.3 & 11.5 & 0.4 & 2.1 & 0.7 \\
Viscous liquid sludge, $1,000^{\circ} \mathrm{C}$ & 31.9 & 10.7 & 0.4 & 1.4 & 1.3 \\
Limed sludge, $400^{\circ} \mathrm{C}$ & 11.8 & 12.8 & 0.4 & 0.8 & 1.0 \\
Limed sludge, $600^{\circ} \mathrm{C}$ & 14.1 & 8.5 & 0.6 & 1.1 & 1.4 \\
Limed sludge, $800^{\circ} \mathrm{C}$ & 7.8 & 6.2 & 1.2 & 0.4 & 0.9 \\
\hline
\end{tabular}




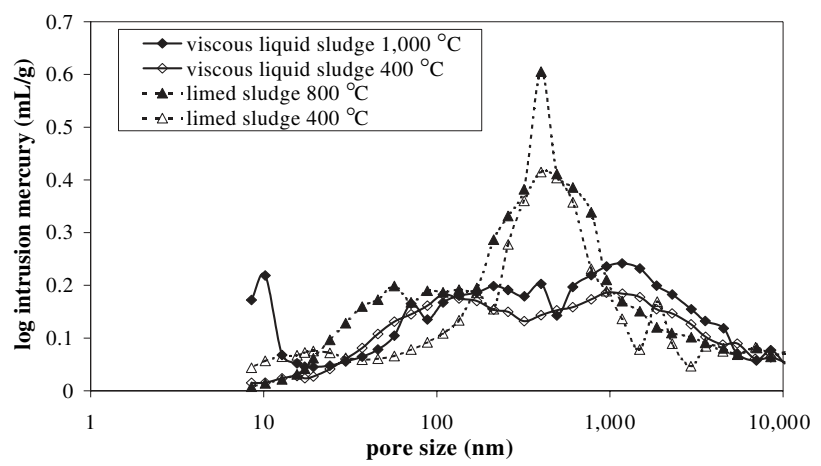

Figure 4 Effect of temperature on pore size distributions of carbonized sludge at $20^{\circ} \mathrm{C} / \mathrm{min}$

tion temperature involves the increase of macroporosity of the carbonized viscous liquid sludge, corresponding to a pore diameter of about $1,100 \mathrm{~nm}$. The same phenomenon is observed in the case of carbonized limed sludge but mesoporosity development corresponds in this case to pore sizes between $25 \mathrm{~nm}$ and $100 \mathrm{~nm}$, and about $600 \mathrm{~nm}$ for macroporosity development. Finally, when the viscous liquid sludge is carbonized at $1,000^{\circ} \mathrm{C}$, mesoporosity development corresponding to pore size of about $9 \mathrm{~nm}$ occurs. The increase of macropores and mesopores volumes with increasing temperature could be the result of chemical alteration within the inorganic matter and the carbon-inorganic matter interface (Bagreev et al., 2001).

Mesopore and macropore distributions of carbonized sludges for different heating rates are presented in Figure 5. For both types of sludge, macroporosity increases with increasing heating rate. Mesoporosity development is also observed within limed sludge when the carbonization heating rate increases. The developed pore sizes are about $1,100 \mathrm{~nm}$ and $100 \mathrm{~nm}$ for carbonized viscous liquid sludge and about $600 \mathrm{~nm}$ and 25-100 nm for carbonized limed sludge.

Specific surface area and micropore volume are determined by nitrogen adsorption/desorption isotherms at $77 \mathrm{~K}$ and the results are presented in Figure 6. Specific surface area and micropore volume generally increase with increasing carbonization temperature, except at $800^{\circ} \mathrm{C}$ for viscous liquid sludge. In the case of limed sludge carbonization, the highest values of specific surface area and micropore volume are obtained at $800^{\circ} \mathrm{C}$ and are equal to $63.1 \mathrm{~m}^{2} \cdot \mathrm{g}^{-1}$ and $0.023 \mathrm{~cm}^{3} \cdot \mathrm{g}^{-1}$ respectively. When the temperature is fixed to the value $1,000^{\circ} \mathrm{C}$, the specific surface area of carbonized viscous liquid sludge reaches $96 \mathrm{~m}^{2} \cdot \mathrm{g}^{-1}$ and the micropore volume is equal to $0.036 \mathrm{~cm}^{3} . \mathrm{g}^{-1}$ respectively. These values are in agreement with literature data. Indeed, Bagreev et al. (2001) have carried out similar sludge car-

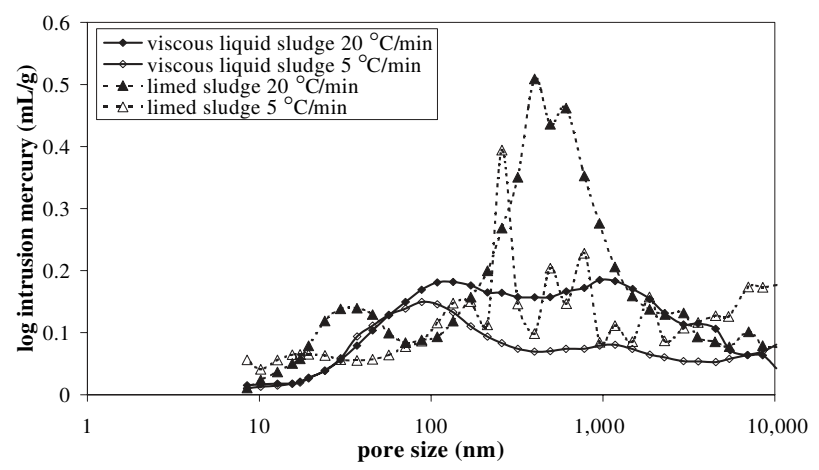

Figure 5 Effect of heating rate on pore size distributions of carbonized sludge at $600^{\circ} \mathrm{C}$ 


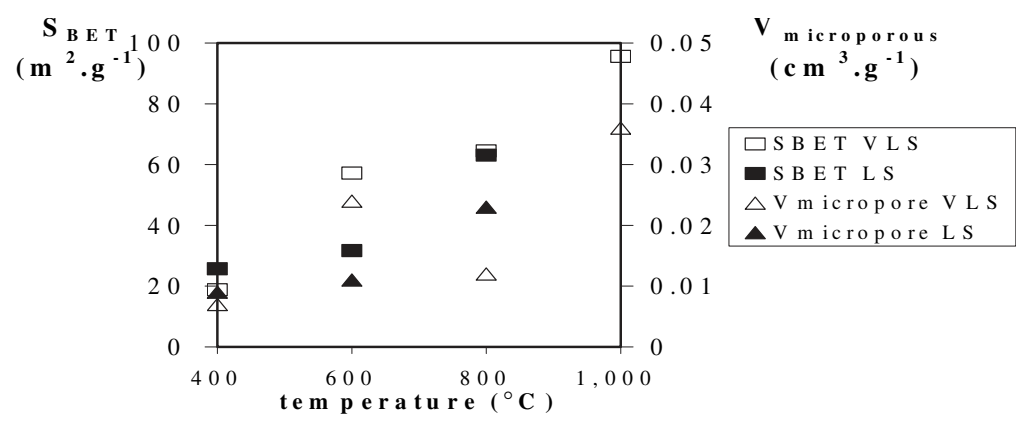

Figure 6 Specific surface area and micropore volume of carbonized sludges versus carbonization temperature. VLS: viscous liquid sludge, LS: limed sludge

bonization experiments and at $950^{\circ} \mathrm{C}$, they obtained a specific surface area of $111 \mathrm{~m}^{2} \cdot \mathrm{g}^{-1}$ and micropore volume of $0.042 \mathrm{~cm}^{3} \cdot \mathrm{g}^{-1}$. Lu et al. (1995) have obtained specific surface area value of $85 \mathrm{~m}^{2} \cdot \mathrm{g}^{-1}$ when carbonization experiments were carried out at $850^{\circ} \mathrm{C}$. All the carbonized samples are mainly mesoporous except the viscous liquid sludge carbonized at $600^{\circ} \mathrm{C}$ in which the micropore volume represents about $50 \%$ of the porosity. Sewage sludge contains micro-organisms whose major components are polysaccharides and peptidoglycans. The polysaccharides would be volatilised at a low carbonization temperature to form macropores and mesopores. Then, when the temperature is higher than $600-700^{\circ} \mathrm{C}$, the peptidoglycans are cracked to form mesopores and micropores (Chiang et al., 2001).

\section{Adsorption tests}

Phenol and benzoic acid adsorption studies are carried out on the carbonized sludges studied. The adsorption kinetic equilibrium is reached after stirring carbonized sludge in aqueous solutions of organic pollutants for 3 days. The equilibrium adsorption capacities for phenol and benzoic acid versus carbonization temperature are presented in Table 3 . The highest adsorption capacities of phenol are obtained when the sludges are carbonized at $600^{\circ} \mathrm{C}$ and reach $33.6 \mathrm{mg} . \mathrm{g}^{-1}$ for viscous liquid sludge and $31.6 \mathrm{mg} . \mathrm{g}^{-1}$ for limed sludge. Then, the best result of benzoic acid removal is also achieved at this temperature when limed sludge is used as a precursor and the corresponding adsorption capacity is equal to $34.2 \mathrm{mg} . \mathrm{g}^{-1}$. For carbonized viscous liquid sludge, Table 3 shows that the adsorption capacity of benzoic acid increases with increasing carbonization temperature and, at $1,000^{\circ} \mathrm{C}$, is equal to $35.1 \mathrm{mg} \cdot \mathrm{g}^{-1}$.

If the specific surface area and micropore volume development of viscous liquid sludge versus carbonization temperature are compared to the results of phenol adsorption experiments, we observe the same evolution with a maximum reached at $600^{\circ} \mathrm{C}$. Specific surface area and micropore volume development would control the phenol adsorption process onto carbonized viscous liquid sludge. Furthermore, in the case of limed sludge, although specific surface area and micropore volume increase with increasing carbonization temperature until $800^{\circ} \mathrm{C}$, the highest adsorption capacities of phenol and benzoic acid are obtained at $600^{\circ} \mathrm{C}$ and not $800^{\circ} \mathrm{C}$. The porous structure of solid residue from limed

Table 3 Results of phenol and benzoic acid adsorption tests

\begin{tabular}{|c|c|c|c|c|c|c|c|}
\hline \multirow{2}{*}{$\begin{array}{l}\text { Type of sludge } \\
\text { Carbonization temperature }\left({ }^{\circ} \mathrm{C}\right)\end{array}$} & \multicolumn{3}{|c|}{ Limed sludge } & \multicolumn{4}{|c|}{ Viscous liquid sludge } \\
\hline & 400 & 600 & 800 & 400 & 600 & 800 & 1,000 \\
\hline Qe,phenol $\left(\mathrm{mg} \cdot \mathrm{g}^{-1}\right)$ & 23.2 & 31.6 & 29.8 & 25.3 & 33.6 & 27.3 & 32.2 \\
\hline Qe,benzoic acid $\left(\mathrm{mg} \cdot \mathrm{g}^{-1}\right)$ & 29.3 & 34.2 & 31.48 & 27.3 & 30.4 & 33.8 & 35.1 \\
\hline
\end{tabular}


sludge carbonization experiments would not be the single property governing the organic pollutants adsorption process. The inorganic matter conversion within limed sludge during carbonization may have an influence on adsorption efficiency.

\section{Conclusions}

The first step of activated carbon production from sewage sludge, namely carbonization, allows us to prepare carbonaceous materials owning interesting adsorption properties. The solid residue resulting from thermal treatment seems to be encouraging for the development of an overall process of sludge valorisation into activated carbon for preservation of the environment. Further experiments will be carried out to convert carbonized sludges into activated carbons by either physical or chemical activation process.

\section{Acknowledgements}

The authors wish to acknowledge ADEME for financial support. The authors are also grateful to Communauté Urbaine de Nantes and M. Orain of Loire 21 for supplying sewage sludge. The experimental assistance of Y. Gouriou (Ecole des Mines de Nantes) and J.C. Poussin (LGSPD, Ecole des Mines d'Albi-Carmaux) throughout this work is gratefully acknowledged.

\section{References}

Bagreev, A., Bandosz, T.J. and Locke, D.C. (2001). Pore structure and surface chemistry of adsorbents obtained by pyrolysis of sewage sludge-derived fertilizer. Carbon, 39, 1971-1979.

Bansal, R.C., Donnet, J.-B. and Stoeckli, F. (1988). Active carbon. Marcel Dekker Inc., New York, USA.

Barbe, J., Brocheton, D., Kockmann, F. and Wiart, J. (2001). Les boues chaulées des stations d'épuration municipales: production, qualité et valeur agronomique. ADEME éditions, Paris, France.

Barrett, E.P., Joyner, L.G. and Halenda, P.P. (1951). The determination of pore volumes and area distributions in porous substances. J. Am. Chem. Soc., 73, 373-380.

Bien, J.B., Bien, J.D. and Matysiak, B. (2000). Research on possibilities of sewage sludge utilisation in the process of pyrolysis. Environ. Sci. Res., 58, 103-111.

Brunauer, S., Emmet, P.H. and Teller, F. (1938). Surface area measurements of activated carbons, silica gel and other adsorbents. J. Am. Chem. Soc., 60, 309-319.

Calvo, L.F., Otero, M., Moran, A. and Garcia, A.I. (2001). Upgrading sewage sludges for adsorbent preparation by different treatments. Biores. Tech., 80, 143-148.

Chiang, H.-L., Chao, C.-G., Chang, C.Y., Wang, C.F. and Chiang, P.C. (2001). Residue characteristics and pore development of petrochemical industry sludge pyrolysis. Wat. Res., 35, 4331-4338.

Horvath, G. and Kawazoe, K. (1983). Method for the calculation of effective pore size distribution in molecular sieve carbon. J. Chem. Eng. Jpn., 16, 470-475.

Inguanzo, M., Menendez, J.A., Fuente, E. and Pis, J.J. (2001). Reactivity of pyrolysed sludge in air and $\mathrm{CO}_{2}$. J. Anal. Appl. Pyrol., 58-59, 943-954.

Lu, G.Q., Low, J.C.F., Liu, C.Y. and Lua, A.C. (1995). Surface area development of sewage sludge during pyrolysis. Fuel, 74, 344-348.

Tay, J.H., Chen, X.G., Jeyaseelan, S. and Graham, N. (2001). A comparative study of anaerobically digested and undigested sewage sludges in preparation of activated carbons. Chemosphere, 44, 53-57.

Zheng, G. and Kozinski, J.A. (2000). Thermal events occurring during the combustion of biomass residue. Fuel, 79, 181-192. 